\title{
Beyond the EJ model: entrepreneurial orientation and industry choice of Ghanaian entrepreneurs
}

\author{
George Acheampong D
}

\section{Correspondence: geoacheampong@ug.edu.gh Department of Marketing and Entrepreneurship, University of Ghana Business School, Accra, Ghana}

\begin{abstract}
This paper seeks to understand an entrepreneur's decision to either the services or manufacturing sectors of the Ghanaian economy. This objective is significant because it provides an extension of current stream of literature, specifically, the Evans and Jovanovic (EJ) Model which focuses largely on an entrepreneur's decision to start a business. The study seeks to understand the industry choice of an entrepreneur by adopting the entrepreneurial orientation concept as its theoretical base. Data for the study is collected from entrepreneurs in Accra, Ghana and analysed by means of structural equation modelling precededwhich is by a confirmatory factor analysis of the entrepreneurial orientation (EO) scale. The estimation results indicate that, entrepreneurs with high risk-taking thresholds are more likely to enter into the manufacturing sector while innovative individuals are more likely to enter into the services sector. Proactiveness is not seen to be significant. The results show that an entrepreneur's personal characteristics influence the choice of industry he or she will participate in.
\end{abstract}

Keywords: Entrepreneurial orientation, Industry choice, Entrepreneurs, EJ Model, Ghana

\section{Background}

Entrepreneurial choice as part of the entrepreneurship literature has gained significant attention since the work of Evans and Jovanovic (1989). The literature has largely focused on theentrepreneurs' decisions to start their own business. Evans and Jovanovic (1989) focused on the idea of entrepreneurial choice under conditions of liquidity constraints. By implication, even though wealthier people may not necessarily be entrepreneurs, poor people cannot also start a business. This is mainly because adequate capital is one of the major requirements of starting any meaningful enterprise. There have been many reactions to this finding, key among them is Xu (1998) who reestimated the Evans-Jovanovic (EJ) model and found a positive correlation instead of negative as found by Evansand Jovanovic. Some authors have however argued that,liquidity constraints are not a necessary and sufficient condition for venturing into enterprise (Cressy, 1999), while others believe that external financing and the possibilities of high returns influence the entrepreneurial choice (Gentry and Hubbard 2000). Harada and Kijima (2005) have also attempted to provide an explanation into the EJ Model by indicating that consumption of leisure influences entrepreneurial choice and

(c) The Author(s). 2017 Open Access This article is distributed under the terms of the Creative Commons Attribution 4.0 International License (http://creativecommons.org/licenses/by/4.0/), which permits unrestricted use, distribution, and reproduction in any medium, provided you give appropriate credit to the original author(s) and the source, provide a link to the Creative Commons license, and indicate if changes were made. 
hence wealth and entrepreneurship can be positively related without liquidity constraints. Beyond the debate, albeit important, surrounding the EJ Model others have looked at other factors that influence entrepreneurial choice. Some of the findings have included age (Lévesque and Minniti, 2006), location (Glaeser and Kerr 2009), income taxes (Fossen and Steiner 2008), gender (Fossen, 2012), income and job creation (Burke et al., 2000), education (Block et al., 2011) and credit constraints (Aghion et al., 2007).

Majority of the literature on entrepreneurial choice seems to centre on the decision to start an enterprise (Cressy, 1999; Harada and Kijima, 2005; Ramadani et al., 2015b; Ramadani et al., 2015a). Entrepreneurs however make choices beyond the decision to enter into a business but also the kind of business (by this industry) they want to enter. [The debate seems to have found no space for this practice of most entrepreneurs]. Again, the EJ model seems to assume risk neutrality while in reality entrepreneurs differ in their risk threshold (Brockhaus, 1980; Palich and Ray Bagby, 1995). Therefore, assuming risk neutrality may not model the reality. Again, entrepreneurs make decisions based on their innovation and proactive tendencies. The EJ model captures this as entrepreneurial ability and measures it using business acumen. However, innovative and proactive behaviour goes beyond just general business acumen but a creative destructive tendency (Schumpeter, 1942) and competitive posture(Kickul and Gundry, 2002). Using the debate on the EJ model as a point of departure, the study attempts to measure the predictive abilities of risk-taking, innovation and proactive behaviours (entrepreneurial orientation- EO) of entrepreneurs on their decision to enter into a particular industry or not,be it service sector or themanufacturing sector. Using weighted least squares with mean variances method of estimation; our key finding suggests that, the decision to enter into a particular industry is mainly influenced by innovation and risk-taking,while proactiveness has no effect. Innovation has a negative relationship with the manufacturing industry.

This study makes two main contributions to the entrepreneurship discourse.The first is that it shifts the discussion from what influences an individual to move into selfemployment (entrepreneurship) to what industry they decide to venture into (Lévesque and Minniti, 2006; Engle et al., 2010).In agreement with the ideas of Lévesque and Minniti (2006) and Engle et al. (2010), this study seeksto further contribute to literature byexploring how entrepreneurs' own attributes, and the opportunities available in an industry can influence their industry choice to operate. Contextually a study like this is clearly warranted in Ghana, as most empirical studies regarding the issue under investigation are developed country bias.

Secondly, we also extend the discussion on the outcomes of entrepreneurial orientation (EO). Extant entrepreneurship literature have generally focused on firm level outcomes of EO such as performance (Wiklund and Shepherd, 2003; Naldi et al., 2007; Rauch et al., 2009) and internationalization (Javalgi and Todd, 2011), partially ignoring the predictors of EO concept. This study presents an extension of the stream of literature through the examination of predictors such as entrepreneurs' predictive abilities of risk-taking, innovation and proactive behaviours and its impact on EO. The remainder of this paper discusses the entrepreneurial orientation (EO) literature and develops hypotheses for testing. The research methods utilized in this study and the results from the analysis are presented in greater detail. Finally, the results are discussed and positioned in relation to existing literature with conclusions drawn from it. 


\section{Theory and hypotheses}

Over the years, literature has considered a number of factors that influences an entrepreneur's choice of industry within which to conduct any economic activity.Recent studies (Cassar, 2014; Kiss and Barr, 2015; Ahmad et al., 2014; Lofstrom et al. (2014) have also attempted to explore how industry type influences entrepreneur choice. Empirical results from these studies show that a positive relationship exists between an industry type and anentrepreneur's decision to venture into a particular kind of business. This provides a strong support to the assertion that, an entrepreneur's choice of operating a particular business is dependent on industry type.However, there has been little emphasis on how an individual's entrepreneurial orientation plays a vital role in the industry choice. Entrepreneurial Orientation is one of the commonly discussed concepts in the entrepreneurship literature. Covin and Slevin(1989) defined Entrepreneurial Orientation (EO) as a strategic posture of a firm which indicates a firm's overall competitiveorientation. Miller (1983) identified some dimensions by which entrepreneurial orientation can be measured - risk-taking, innovative and proactive behaviours. Thus, when a firm or individual exhibits innovative, proactive, and risk-taking behaviours, that firm or individual is said to be entrepreneurially oriented. Similarly, Dess, Lumpkin and Covin, (1997) characterized Entrepreneurial Strategy Making along the dimensions of innovativeness,risk taking and proactive assertiveness. Conversely, a non-entrepreneurialstyle is characterizedas being risk-averse, non-innovative,passive and reactive (Covin and Slevin, 1988). Some scholars discovered that there are differences between manufacturing and service firms when it comes to innovation processes (Preissl, 2000).

\section{Risk-taking and industry choice}

Risk taking dimension according to Miller and Friesen (1978; p. 923)is "the degree to which entrepreneurs are willing to make largeand risky resource commitments - i.e. those which have a reasonable chance of costlyfailures." Lumpkin and Dess (2001) further explain risk taking as the tendencyto take bold actions such as venturing into unknown new markets, committinga large portion of resources to ventures with uncertain outcomes, and/or borrowingheavily. Preissl (2000) discovered that manufacturing enterprises typically require a higher resource commitment than service enterprises. Hence, from a resource point-of-view, one can argue that manufacturing enterprises take more risk than their service counterparts (Cooper and Kleinschmidt, 1987). Thus, entrepreneurs that enter the service sector may be risk averse compared to the entrepreneurs that enter the manufacturing sector. Consequently, it is hypothesized that:

\section{H1: Entrepreneurs with a propensity to take risks are more likely to enter the} manufacturing sector

\section{Innovativeness and industry choice}

The innovation dimension is "the tendency of a firm 'or individual' to engage in and support newideas, experimentation and creative processes that may result in new products, services or technological processes" (Lumpkin and Dess, 1996; p. 142). Schumpeter (1934) first highlighted the importanceof innovation for entrepreneurship. He sees an entrepreneur 
as an innovator who is able to introduce something new - product/service, methods of production/organizational methods, market and sources of raw materials to the economy (Buame, 2012). Thus, innovation depends on the characteristicsof entrepreneurs who face a dynamic environment. In other words, the entrepreneur decides which industry to enter depending on his/her abilities to innovate to suite changing market needs. Sundbo (2010) and Toivonen (2010; p. 223-224) posit that the service industry is passive and rather adopts technological innovation produced in the manufacturing sector, which has a more rational RandD-based innovation development and can be more efficient and economically beneficial. Typically, service innovation processes are less structured and often non-technical, two reasons why it can be argued that service innovations can be achieved more easily than product innovations (Sundbo, 1998). However, given the intangibility nature of services, it is relatively easier to imitate than products that are tangible (Gronroos, 1978). Therefore, entrepreneurs that enter services must therefore continually innovate to stay relevant in the industry.Consequently, it is hypothesized that:

H2: Entrepreneurs with high innovative skills are more likely to enter into service industry compared to manufacturing industry

\section{Proactiveness and industry choice}

Krieser, Marino and Weaver (2002) suggest that the proactiveness dimension of entrepreneurial orientation has received less attention from researchers.Proactiveness is acting anticipatorily in order to shape the environment byinfluencing trends and creating demand and becoming a first mover in a competitivemarket (Lumpkin and Dess, 1996). Proactiveness has also been defined as a response toopportunities (Lumpkin and Dess, 2001). Proactive individuals take initiative and becomeleaders in the marketplace by exploiting opportunities. These individuals explore theresources, seek opportunities in the market and create new niches which requireexperimentation and discovery (Lumpkin and Dess, 2001).As stated above, proactiveness represents behaviours in anticipation of future problems, needs, and changes. It involves taking the initiative, anticipating and carrying out new opportunities, and the creation of or participation in emerging markets (Entrialgo, Fernández,and Vázquez, 2000). Proactiveness is thus a dimension that depends on and interacts with market conditions. Manufacturing industries require a high lead time to respond to market changes. Hence, anticipatory behaviour is required to be able to configure manufacturing processes. It is therefore hypothesized that:

H3: Proactive entrepreneurs are more likely to enter into manufacturing rather than service industry

\section{Methods}

This was a cross-sectional study conducted between October and December 2015 in Greater Accra Metropolitan Area (GAMA) in Ghana. The study divided GAMA into four classes of major areas based on Accra Metropolitan Area's (AMA) industry classification which is based on the enterprise demographic characteristics in the area. ${ }^{1}$ The study selected three (3) industrial clusters in each class using simple random sampling method, amounting to a total of 12 communities (Acheampong and Esposito, 2014). 
Each community was allocated 60 enterprises. Within the clusters, systematic sampling was used to select enterprises. Every ninth enterprise in these clusters was interviewed. Adopting an interviewer administered questionnaire approach, both questionnaire and interviews were deemed appropriate for eliciting responses from respondents sampled for this study. The study sent out a total of 600 questionnaires of which 300 were usable representing a 50\% response rate. The unit of analysis in this study were SME owner-managers. These are people who own SMEs in Ghana (Dana, 2007). The study developed a structured questionnaire after an extensive literature review on entrepreneurial orientation. The questionnaire measured issues like risk-taking, innovativeness and proactiveness as independent variables. The dependent variable was the industry in which therespondents' businesses operated. This could be the service or manufacturing sector. The study also included control variables such as age of the entrepreneur, the gender and educational level. Table 1 presents a detailed description of the data utilized for the study. The questionnaires, which were in English, were translated into Twi, Ga, Ewe and Hausa (local languages of study areas) and then back-translated into English. The interviews were conducted in local languages. It is worth mentioning that, the researchers are fluent in the local languages. Pretesting exercises were conducted repeatedly among the field staff and respondents from selected locations before carrying out the actual survey. The study employs structural equation modelling (SEM) utilizing the MPlus software (Muthen and Muthen 2007) to assess the posited

Table 1 Descriptive Statistics

\begin{tabular}{|c|c|c|c|}
\hline Variable & Mean & Alpha & Items \\
\hline Risk-Taking & 3.93 & 0.833 & I consider myself daring \\
\hline \multirow[t]{4}{*}{$\begin{array}{l}{[1=\text { Strongly disagree; } 5=} \\
\text { Strongly Agree }]\end{array}$} & & & $\begin{array}{l}\text { I take bold decisions necessary to achieve the firm's } \\
\text { objectives }\end{array}$ \\
\hline & & & I understand risk-taking and how it works \\
\hline & & & $\begin{array}{l}\text { The term "risk taker" is considered a positive attribute for } \\
\text { people in our business }\end{array}$ \\
\hline & & & $\begin{array}{l}\text { People in our business are encouraged to explore and } \\
\text { develop new ideas }\end{array}$ \\
\hline Innovativeness & 3.92 & 0.679 & I am motivated to be creative in methods of operation \\
\hline $\begin{array}{l}{[1=\text { Strongly disagree; } 5=\text { Strongly }} \\
\text { Agree }]\end{array}$ & & & I have a strong emphasis on product/service gaps \\
\hline Proactiveness & 4.09 & 0.827 & I take the lead and competitors follow \\
\hline \multirow{2}{*}{$\begin{array}{l}{[1=\text { Strongly disagree; } 5=} \\
\text { Strongly Agree }]\end{array}$} & & & I am not afraid to fail \\
\hline & & & I adopt a very competitive posture \\
\hline \multirow[t]{2}{*}{ Gender } & Male & & $62.3 \%$ \\
\hline & Female & & $37.7 \%$ \\
\hline \multirow[t]{3}{*}{ Age } & $\leq 25 \mathrm{y}$ & 'ears & $11.3 \%$ \\
\hline & $26-45 y$ & years & $68.0 \%$ \\
\hline & $\geq 46 y$ & ears & $20.7 \%$ \\
\hline \multirow[t]{3}{*}{ Education } & $\begin{array}{l}\leq \text { Basic } \\
\text { School }\end{array}$ & & $51.7 \%$ \\
\hline & Seconc & dary & $44.0 \%$ \\
\hline & $\geq$ Univ & versity & $4.3 \%$ \\
\hline \multirow[t]{2}{*}{ Industry } & Service & & $63.0 \%$ \\
\hline & Produc & ction & $37.0 \%$ \\
\hline
\end{tabular}


relationships among all the constructs. According to Nielsen and Nielsen (2009) SEM is very useful in assessing a proposed theoretical model since it enables simultaneous estimation of multiple relationships among observed and latent constructs while accounting for the measurement error. The study also employed the commonly established two-stage method prosed by Anderson and Gerbing (1988). Step one involves a confirmatory factor analysis (CFA) to examine the validity of the measurement model and the discriminant validity of individual constructs. Step two involves a structural model to estimate the path coefficients and test for the relationships among constructs. A sequence of nested structural models (competing models) were evaluated in order to determine the model that represents the best fit between the hypothesized relationships and the observed variance in the data (Nielsen and Nielsen 2009).

\section{Results and discussion}

The study used a confirmatory factor analysis to assess the psychometric properties of the scaled items for constructs derived from the Covin and Slevin entrepreneurial orientation scale. Table 1 present a descriptive statistics derived from the study respondents. Risk taking was composed of 5 items with a mean of 3.93 and an alpha of 0.833 . Innovativeness was measured with two items with a mean value of 3.92 and an alpha value of 0.679. Proactiveness was measured with three items with a mean of 4.09 and an alpha value of 0.827 . Majority of the study respondents were male (62.3\%) with most of the respondents aged between 26 and 45 years (68\%). Most of the entrepreneurs that were surveyed had basic education or less (51.7\%) while the industry of choice was theservices sector. The demographic profile is very indicative of the nature of business environment in Ghana(Abor and Quartey 2010). With respect to the measurement model, the proposed model displayed a good level of fit with the data $(C F I=0.958$; RMSEA $=0.056 ; \quad$ WRMR $\left.=0.828 ; X^{2}=99.42952 ; p<0.05\right)$ using multiple fit indices (Schreiber et al. 2006; Hooper et al. 2008). The study then went on to test for three structural models (one is the main effects hypothesized; two is the control effects of demographic factors; three is the combined effects of both the main and control effects). It is important to note that the models here are not nested. Structural models are used to assess the validity of causal structures among latent variables. Structural model I reported these fit indices $\left(\mathrm{CFI}=0.953\right.$; $\mathrm{RMSEA}=0.078$; $\mathrm{WRMR}=0.653 ; X^{2}=$ $\left.136.339_{49} ; p<0.05\right)$ and was accepted as adequately modelling the data. Structural models II (CFI $=0.584 ;$ RMSEA $=0.152 ;$ WRMR $\left.=2.271 ; X^{2}=642.57482 ; p<0.05\right)$ and III $\left(\mathrm{CFI}=0.629 ; \mathrm{RMSEA}=0.141 ; \mathrm{WRMR}=2.284 ; X^{2}=585.598_{85} ; p<0.05\right)$ were rejected for inadequate fit with the data. The models were estimated using weighted least squares with mean variances (WLSMV) since the dependent variable was categorical (Muthen 1984). Please see Table 2 for model fit indices for measurement and structural models. Using structural model, I identified in Table 2 the study proceeded to examine the hypotheses using the parameter estimates. All path coefficients used are the unstandardized coefficients. In hypothesis one the anticipated positive relationship between risk-taking and entrepreneurs' industry choice was supported $(\beta=+2.508 ; p<0.001)$. Hypothesis two which explored positive relationship between innovativeness and entrepreneurs' industry choice was not supported $(\beta=-2.075 ; p<0.05)$. A negative and significant relationship was found. Hypothesis three which explored positive relationship between proactiveness and entrepreneurs' industry choice was not supported $(\beta=-0.029 ; p>0.05)$. 
Table 2 Model Fit Indices

\begin{tabular}{lllll}
\hline Model & CFI & WRMR & RMSEA & Chi-Square \\
\hline Measurement model & 0.958 & 0.828 & 0.056 & $99.429_{52} ; p<0.05$ \\
Structural model I & 0.953 & 0.653 & 0.078 & $136.339_{49} ; p<0.05$ \\
Structural model II & 0.584 & 2.271 & 0.152 & $642.574_{82} ; p<0.05$ \\
Structural model III & 0.629 & 2.284 & 0.141 & $585.598_{85} ; p<0.05$ \\
\hline
\end{tabular}

This study seeks to understand why entrepreneurs enter certain industries and not others. The focus is on the decision of the entrepreneur to enter either the manufacturing or services sector of the Ghanaian economy. The entrepreneurial orientation theoretical framework is used to theorize this relationship. The study utilizes data from Ghanaian entrepreneurs to test for the empirical relationship between these two constructs. In this section, the study presents a discussion and implications of the findings. In hypothesis 1, the paper argues that entrepreneurs with high risk-taking propensities are more likely to enter into manufacturing compared to services. The empirical findings confirm this claim. This finding confirms the assertion of Preissl (2000) who mentioned that manufacturing enterprises typically require a higher resource commitment than service enterprises and Cooper and Kleinschmidt (1987) who argues from a resource point-of-view that, manufacturing enterprises take more risk than their service counterparts. In hypothesis 2, the paper argues that entrepreneurs that have a higher innovative propensity are more likely to enter into the services sector. This argument was confirmed by the empirical analysis. The finding confirms Sundbo (1998) and Gronroos (1978) argument that services are intangible and can easily be imitated and hence to be relevant in such an industry it is important to be continuously innovating. This is in sharp contrast to recent arguments in the literature that seem to suggest that the service industry is passive and rather adopts technological innovation produced in the manufacturing sector, which has a more rational RandD-based innovation development and can be more efficient and economically beneficial (Sundbo, 2010; Toivonen, 2010). Hypothesis 3 is observed not to be significant in the empirical analysis. This can be because in both industries it is critical to be proactive in understanding the industry dynamics to be relevant. Hence, the variation between these two industries will not be significant.

From the findings of the study, it can be mentioned that Evans and Jovanovic's (1989) model strongly confirms the proposed contributions of this study,as this research extends the literature to provide insightful information and understanding regarding industry choice of entrepreneurs. Thus, thecontribution of this current paper is an extension to existing literature by providing an understanding regarding the predictors that influence industry choice of entrepreneurs. Specifically, from other extant literature, this paper makes an extension to the EJ model.

\section{Conclusion}

This paper seeks to understand an entrepreneur's decision to either the services or manufacturing sectors of the Ghanaian economy.This objective is significant because it provides an extension of current stream of literature that focuses largely on an entrepreneur's decision to start a business. The results indicate that, entrepreneurs with high risk-taking thresholds are more likely to enter into the manufacturing sector while innovative individuals are more likely to enter into the services sector. Proactiveness is 
Table 3 Structural Equation Modelling Results

\begin{tabular}{lllccl}
\hline Hyp & Description of Path & Hypothesized Direction & Control Effects (II) & Main Effects (I) & Combined Effects (III) \\
\hline H1 & Risk-taking & + & & $+2.508^{* * *}$ & $+2.123^{* *}$ \\
H2 & Innovativeness & + & & $-2.075^{*}$ & $-1.738^{*}$ \\
H3 & Proactiveness & + & & -0.029 & -0.150 \\
& Gender & & $-0.775^{* * *}$ & & $-0.775^{* * *}$ \\
& Age & & & $+0.747^{* * *}$ \\
& Education & & +0.048 & & +0.048 \\
\hline
\end{tabular}

$N=295$, all path coefficients are non-standardized estimates

$+p<0.001^{* * *} ; p<0.01^{* *} ; p<0.05^{*}$

not seen to be significant. The results also show that an entrepreneur's personal characteristics influence the choice of industry he or she will participate in (Table 3).

Additionally, it is noteworthy to mention that, the two contributions this study made to literature were severally and variously confirmed by extant scholars. First, there has been a call by Harada and Kijima (2005) for an extension of the already existing Evans and Jovanovic (EJ) Model since it comes with some critics. Second, several scholars (Brockhaus 1980; Palich and Ray Bagby 1995) are in support of the view that understanding the predictors of EO serves as a mechanism that guidesentrepreneurs to achieve outstanding outcomes.

Further, this study generally has both managerial and theoretical implications. Managerial implications provide insights for practitioners while theoretical and research implications provide insights that form the bedrock of future research (Acheampong and Kumah, 2011). This study makes eminent literature contribution in three strands. Thus, practice, policy and research. From a practical point of view, the findings of this study would inform management and practitioners on the influence of entrepreneurs' predictive abilities of risk-taking, innovation and proactive behaviours on EO. Management would be able to identify which of the predictors to focus on to increase EO. The policy lessons drawn from the respondents under this study would provide a guide to management and policy makers. For instance, it would provide insight on what management and policy makers must be mindful of in achieving outstanding EO. From the research perspective, the study will add to the nearly non-existing literature from the Ghanaian perspective. Besides the context, knowledge and issue gaps identified in literature this study seeks to fill, the study will serve as a guide for future research.

\section{Endnotes}

${ }^{1}$ www.ghanadistricts.com

\section{Acknowledgements}

The author wishes to acknowledge the support provided by Gloria Adu-Darko and Patrick Amfo Anim, research assistants at the Department of Marketing and Entrepreneurship of the University of Ghana Business School.

Funding

This paper was self-funded by the author.

Authors' contributions

The author collected data, analysed it and wrote-up the whole manuscript. 


\section{Publisher's Note}

Springer Nature remains neutral with regard to jurisdictional claims in published maps and institutional affiliations.

Received: 7 May 2017 Accepted: 24 November 2017

Published online: 22 December 2017

\section{References}

Abor, J, \& Quartey, P. (2010). Issues in SME development in Ghana and South Africa. International Research Journal of Finance and Economics, 39, 218-228.

Acheampong, G, \& Esposito, M. (2014). The nature of entrepreneurship in bottom of the pyramid markets. International Journal of Entrepreneurship and Small Business, 21, 437-456.

Acheampong, G, \& Kumah, B. (2011). Impact of firm-level factors and market entry mode on performance: a study of service MNCs in an emerging economy. Management Science Letters, 2(2), 631-646.

Aghion, P, Fally, T, Scarpetta, S. (2007). Credit constraints. Economic Policy October, 2007, 732-779.

Ahmad, SZ, Jabeen, F, Khan, M. (2014). Entrepreneurs choice in business venture: Motivations for choosing home-stay accommodation businesses in peninsular Malaysia. International Journal of Hospitality Management, 36, 31-40.

Anderson, JC, \& Gerbing, DW. (1988). Structural equation Modeling in Practice: A review and recommended two-step approach. Psychological Bulletin, 103, 411-423.

Block, JH, Hoogerheide, L, Thurik, R. (2011). Education and entrepreneurial choice: An instrumental variables analysis. International Small Business Journal, 31, 23-33. doi:10.1177/0266242611400470.

Brockhaus, RH. (1980). Risk taking propensity of entrepreneurs. The Academy of Management Journal, 23, 509-520. doi: $10.2307 / 255515$

Buame, S. (2012). Entrepreneurship: entrepreneurial education, venture creation, and SME management in Ghana. Accra: Ghana Universities Press.

Burke, AE, FitzRoy, FR, Nolan, M a. (2000). When less is more: Distinguishing between entrepreneurial choice and performance. Oxford Bulletin of Economics and Statistics, 62, 565-587. doi:10.1111/1468-0084.00190.

Cassar, G. (2014). Industry and startup experience on entrepreneur forecast performance in new firms. Journal of Business Venturing, 29(1), 137-151.

Cooper, RG, \& Kleinschmidt, EJ. (1987). New products: what separates winners from losers?. Journal of Product Innovation Management, 4(3), 169-184.

Covin, JG, \& Slevin, DP. (1988). The influence of organization structure on the utility of an entrepreneurial top management style. Journal of Management Studies, 25(3), 217-234.

Cressy, R. (1999). The Evans and Jovanovic equivalence theorem and credit Rationing : Another look. Small Business Economics, 12, 295-297.

Dana, LP. (2007). Promoting SMEs in Africa : Some insights from an experiment in Ghana and Togo. Journal of African Business, 8, 151-174. doi:10.1300/J156v08n02.

Engle RL, Gavidia J V, Schlaegel C, et al (2010) Entrepreneurial intent of planned behavior. 16:35-57. doi:10.1108/ 13552551011020063

Evans, DS, \& Jovanovic, B. (1989). An estimated model of entrepreneurial choice under liquidity constraints. Journal of Political Economy, 97, 808. doi:10.1086/261629.

Fossen, FM. (2012). Gender differences in entrepreneurial choice and risk aversion - A decomposition based on a microeconometric model. Applied Economics, 44, 1795-1812. doi:10.1080/00036846.2011.554377.

Fossen, FM, \& Steiner, V. (2008). Income taxes and entrepreneurial choice: Empirical evidence from two German natural experiments. Empirical Economics, 36(3), 487-513. doi:10.1007/s00181-008-0208-z.

Gentry, W, \& Hubbard, G (2000). Entrepreneurship and household saving. Cambridge, Massachusetts.

Glaeser, E, \& Kerr, W. (2009). Local industrial conditions and Entrepreneurship : How much of the spatial distribution can we Explain? Journal of Economics and Management Strategy, 18, 623-663.

Gronroos, C. (1978). A service-orientated approach to marketing of services. European Journal of Marketing, 12(8), 588-601.

Harada, N, \& Kijima, K. (2005). Consumption-leisure preference structure: A new explanation of the Evans-Jovanovic results for entrepreneurial choice. Small Business Economics, 24, 187-191. doi:10.1007/s11187-003-4300-7.

Hooper, D, Coughlan, J, Mullen, MR. (2008). Structural equation Modelling : Guidelines for determining model fit. Electronic Journal of Business Research Methods, 6, 53-60.

Javalgi, R(R)G, \& Todd, PR. (2011). Entrepreneurial orientation, management commitment, and human capital: The internationalization of SMEs in India. Journal of Business Research, 64, 1004-1010. doi:10.1016/j.jbusres.2010.11.024

Kickul, J, \& Gundry, L. (2002). Prospecting for strategic advantage: The proactive entrepreneurial personality and small firm innovation. Journal of Small Business Management, 40, 85-97. doi:10.1111/1540-627X.00042.

Kiss, AN, \& Barr, PS. (2015). New venture strategic adaptation: The interplay of belief structures and industry context. Strategic Management Journal, 36(8), 1245-1263.

Lévesque, M, \& Minniti, M. (2006). The effect of aging on entrepreneurial behavior. Journal of Business Venturing, 21, 177-194. doi:10.1016/j.jbusvent.2005.04.003

Lofstrom, M, Bates, T, Parker, SC. (2014). Why are some people more likely to become small-businesses owners than others: Entrepreneurship entry and industry-specific barriers. Journal of Business Venturing, 29(2), 232-251.

Lumpkin, GT, \& Dess, GG. (1996). Clarifying the entrepreneurial orientation construct and linking it to performance. Academy of Management Review, 21(1), 135-172.

Lumpkin, GT, \& Dess, GG. (2001). Linking two dimensions of entrepreneurial orientation to firm performance: The moderating role of environment and industry life cycle. Journal of Business Venturing, 16(5), 429-451.

Miller, D. (1983). The correlates of entrepreneurship in three types of firms. Management Science, 29(7), 770-791.

Miller, D, \& Friesen, PH. (1978). Archetypes of strategy formulation. Management Science, 24(9), 921-933.

Muthen, BO. (1984). A general structural equation model with dichotomous, ordered categorical, and continuous laten variable indicators. Psychometrika, 49, 115-132. 
Muthen, LK, \& Muthen, BO (2007). Mplus statistical analysis with latent variables: User's guide. Los Angeles: Muthen and Muthen.

Naldi, L, Nordqvist, M, Sjöberg, K, Wiklund, J. (2007). Entrepreneurial Orientation. Risk Taking, and Performance in Family Firms. Family business review, 20(1), 33-47.

Nielsen, BB, \& Nielsen, S. (2009). Learning and innovation in international strategic alliances: An empirical test of the role of trust and Tacitness. Journal of Management Studies, 46, 1031-1056. doi:10.1111/j.1467-6486.2009.00840.x.

Palich, LE, \& Ray Bagby, D. (1995). Using cognitive theory to explain entrepreneurial risk-taking: Challenging conventional wisdom. Journal of Business Venturing, 10, 425-438. doi:10.1016/0883-9026(95)00082-J.

Preissl, B. (2000). Service innovation: what makes it different? Empirical evidence from Germany. In Innovation systems in the service economy (pp. 125-148). US: Springer.

Ramadani, V, Hisrich, RD, Gërguri-Rashiti, S. (2015a). Female entrepreneurs in transition economies : Insights from Albania, Macedonia and Kosovo. World Review of Entrepreneurship, Management and Sustainable, 11, 391-413.

Ramadani, V, Dana, L-P, Ratten, V, Tahiri, S. (2015b). The context of Islamic entrepreneurship and business : Concept, principles and perspectives. International Journal of Business and Globalisation, 15, 244-261.

Rauch, A, Wiklund, J, Lumpkin, GT, Frese, M. (2009). Entrepreneurial orientation and business performance: An assessment of past research and suggestions for the future. Entrepreneurship Theory and Practice, 33, 761-787. doi:10.1111/j.1540-6520.2009.00308.x

Schreiber, JB, Nora, A, Stage, FK, et al. (2006). Reporting structural equation Modeling and confirmatory factor analysis Results: A review. The Journal of Educational Research, 99, 323-337.

Schumpeter J (1942) Capitalism, socialism and democracy.

Sundbo, J. (1998). The theory of innovation: enterpreneurs, technology and strategy. Edward Elgar Publishing

Sundbo, J. (2010). Public-private networks and servcie innovation in knowledge intensive servcies. A report of European case studies.

Toivonen, M. (2010). Different types of innovation processes in services and their organisational implications. The handbook of innovation and services: A Multi-disciplinary Perspective. 221-249.

Wiklund, J, \& Shepherd, D. (2003). Knowledge-based resources, entrepreneurial orientation, and the performance of small and medium-sized businesses. Strategic Management Journal, 24, 1307-1314. doi:10.1002/smj.360.

$\mathrm{Xu}$, B. (1998). A reestimation of the Evans-Jovanovic entrepreneurial choice model. Economics Letters, 58, 91-95.

Submit your manuscript to a SpringerOpen ${ }^{\circ}$ journal and benefit from:

- Convenient online submission

- Rigorous peer review

Open access: articles freely available online

High visibility within the field

Retaining the copyright to your article

Submit your next manuscript at $>$ springeropen.com 